\title{
Microcurie per Kilogram
}

National Cancer Institute

\section{Source}

National Cancer Institute. Microcurie per Kilogram. NCI Thesaurus. Code C70571.

A unit of specific radioactivity (massic activity) equal to activity of one microcurie of the sample with total mass of one kilogram. 